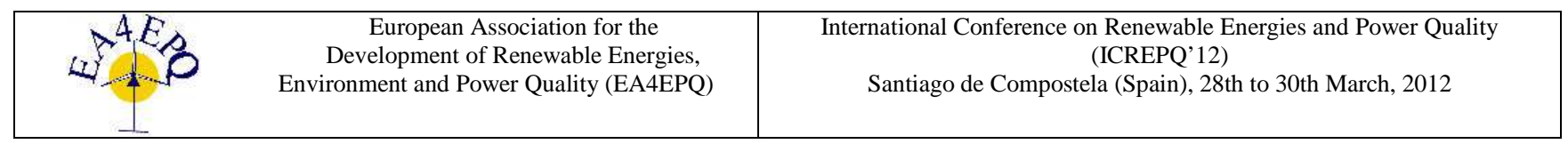

\title{
Feasibility study of biogas in CHP plant for a pig farm
}

\author{
F. Patania ${ }^{1}$, A. Gagliano ${ }^{1}$, F. Nocera ${ }^{1}$ and A. Galesi ${ }^{1}$ \\ ${ }^{1}$ Department of Industrial and Mechanics Engineering \\ D.I.I.M., Catania University \\ Viale Andrea Doria, 6, 95125 Catania (Italy) \\ Phone/Fax number:+0039 320 4332228, e-mail: agagliano@ diim.unict.it, fnocera@ unict.it
}

\begin{abstract}
Cogeneration, or the Combined production of Heat and Power (CHP), is being promoted at EU level as a way of reducing green house gas (GHG) emissions from traditional power plants.

For a long time, CHP systems have been used successfully in industry but it can be developed across numerous market sectors, including zootechnics farms. Currently with the rapid global economic change and the increasing needs for environmental sustainability it is timely to review pig farm heat and electrical power options to reduce costs and optimize environmental outcomes. This paper describes a feasibility study of biogas CHP plant in a medium pig farm in Italy. Biogas, produced by pig manure, is burned in CHP system to satisfy the demand of electricity and heat. Results illustrate how the utilization of gaseous product from pig farm effluent (biogas) as fuel for heat and power generation can reduce both energy cost and $\mathrm{CO}_{2}$ equivalent $\mathrm{GHG}$ emission in the environment.
\end{abstract}

Key words: biogas, CHP, GHG emissions, energy saving

\section{Introduction}

Wastewater digester gas can serve as a fuel substitute for natural gas in applications such as boilers, hot water heaters, reciprocating engines, turbines, and fuel cells.

The gas produced by anaerobic digestion is usually more than 60 percent methane, and some plants with state ofthe-art facilities have the potential to produce a biogas with concentrations of methane that reach up to 95 percent. This biogas is produced on a continuous basis, and contaminants, such as hydrogen sulfide, are removed prior to use. Other processing may include dehydration, filtering, or $\mathrm{CO} 2$ removal [1]

At the moment anaerobic digestion is considered to be one of the best techniques for the treatment of the wastewater from agro-industrial complexes with high organic content. As early as 1994 there were about 400 business and consortium biogas units while now there are more than 3500 anaerobic digesters operating on livestock effluent in all countries of the European Union. The highest number is in Germany followed by Denmark, Austria, Sweden and Italy. [2].
It is estimated that for 2007 the production of biogas by European countries was about 5.901,2 ktoe (ktoe = Kiloton of oil equivalent). Of this figure about $50 \%$ came from the recovery of biogas from urban waste tips [3]. EurObserv'ER forecasts biogas production in 2010 will amount to 7,800 ktoe. Organic refuse produced yearly by European Union countries amounts to about 2.5 billion tons of which about $40 \%$ is livestock effluent and agricultural waste, the remainder made up by urban and industrial waste, sewage sludge and wood-cellulose waste from forestry, the only part that could not be used in anaerobic digestion [4]

The country where anaerobic digestion has been developed the most over the last ten years is Germany, particularly in the livestock sector

This is the result of the policy of incentives adopted by the national government which, in addition to providing a contribution towards the investment, pays a price for electrical energy from biogas which may reach $€$ $0.27 / \mathrm{kWh}$ over a period of 20 years. The situation is different in Italy where EurObserv'ER estimates that biogas production in 2007 stood at 406.2 ktoe (about 4.7 TWh) [2]. Of this about $80 \%$ comes from the recovery of biogas from Municipal Solid Waste (MSW) landfills.

In Italy the biogas plants have been constructed in almost all northern regions. The zones most affected are those with the highest concentration of livestock farms such as Lombardy, Emilia-Romagna and Veneto. Some plants are being constructed in areas where significant quantities of waste and organic bye-products are produced by the agro-industrial sector to be used in codigestion including as a management solution to the recovery of this waste.

Plant numbers are significantly less in the centre and south of Italy.

The number of plants using only pig slurry is worthy of note. Some of these are from the generation of simplified biogas plant mainly constructed at the beginning of the 1990s with a plastic covering fitted to a slurry storage tank and/or lagoon. Subsequently there has been increased interest in Italy as well in the co-digestion of livestock slurries mixed with other biomass such as energy crops and organic waste. 


\section{Biomass - CHP}

Biomass CHP is a way of generating both heat and power from Biomass. Biomass is a renewable energy created from recently living material, such as plants, waste wood or animal fats. As it is a renewable energy, Biomass won't run out, unlike fossil fuels, and is not weather conditions dependant like wind or solar power or water dependent like tidal power or dams consumptions.

In a biomass CHP installation the steam created is used to drive a turbine, which then generates electricity.

This form of generating power is up to $70 \%$ efficient, compared to approximately $40 \%$ for coal and gas fired power stations. This increased efficiency is because the heat created during the power generation process is used, rather than wasted like it is in a fossil fuelled power station. There are also fewer emissions created than in a fossil fuelled power station [5].

CHP can be useful when a constant and reliable supply of electricity is needed all day every day. Using this technology, the company or individual relies less on the national electricity supply. As more people follow suite, there is a reduced demand for electricity, which in turn will reduce the amount of fossil fuels used.

Overseas biogas fuelled CHP plants have traditionally used reciprocating engine power plants i.e. converted automotive engines, converted diesel generator engines or dedicated spark ignition (bio) gas engines. Using these engines the CHP plants with a capacity of less than $200 \mathrm{kWe}$ achieve electrical conversion efficiencies from $25 \%$ to $35 \%$. Major differences between the three types of engines exist in regards to maintenance requirements and cost [1]. In general the failure rate of biogas fuelled reciprocating engines have been a key reason for economic failure of biogas fuelled

CHP plants. An example is the rapid degradation of reciprocating engines' lubricating oil. The trace gases $\mathrm{NH}_{3}$ and $\mathrm{H}_{2} \mathrm{~S}$ contained in raw biogas cause the rapid degradation of the oil. This leads to high maintenance labour requirements and costs as well as high engine failure risks. Therefore alternative types of energy conversion equipment have been investigated. A potential alternative energy conversion technology for the study has been identified in the form of micro sized gas turbine power generators. These machines,

available in sizes from $30 \mathrm{~kW}$, are internationally used with potentially corrosive fuels, notably in the oil and gas industry. This design of turbines consists only of one moving part and operates without lubricating oil. In comparison with reciprocating engines, turbine power generator units achieve slightly lower electrical conversion efficiencies. It was however assumed at this stage that this disadvantage will be more than compensated for by the reduction in risk profile and associated operational costs.

\section{The case study}

The study investigated an electricity generation scheme based on the sow "farrow-to-finish", pig breeding and rearing facility. In particular, the study assessed the technical and economic feasibility for self-handling CHP using biogas coming from pig manure.
The studied farm is located in Sicily (Italy, EU), in Assoro territory. The main structures of the farm are listed below:

- a shed where the pigs are usually housed through their growth stages

- a dry sow shed that housing pregnant sows

- a "birthing" or "farrowing" area where the pregnant sows are moved when they are ready to give birth to her piglets

- a weaning shed where the weaned piglets are kept

- a finishing shed where finisher pigs are housed

- $\quad$ a Mill that produce durum wheat

- a shed where pigs are slaughtered

- a shed where the factory farm produce salami;

- a shed for organic fertilizer production;

- a building that housing offices

- a building that housing a store of salami;

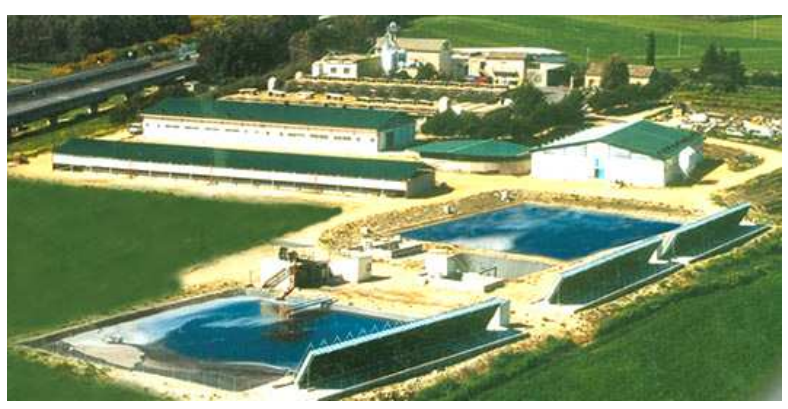

Fig.1: The farm

\subsection{Energy Audit}

The Authors have analyzed and monitored the energy consumption to evaluate the energetic architectural system of the factory farm and improve the efficiency of the system

The energy audit have been carried out as follows:

1. survey and analysis of the consumption and energy requirements (electrical, heating and cooling) for the buildings and/or the production processes.

2. inspection and survey of the equipments and main technologies in use on the farm

3. performance evaluation of the equipments used to produce cooling, heating, lighting, etc.

The Energy Audit has been performed for each production process and for each HVAC equipment in order to identify any critical points and the possible solutions that might allow a reduction of energy consumption through the optimization of the resources.

\subsection{Electricity demands}

Data on electricity bills for the biennium 2007-2008 and for the first months of 2009 have been acquired and all electrical, heating and cooling utilities (installed capacity, hours of work, etc..) have been cataloged in order to identify the utilities that to identify the utilities that present the more high energy consumptions.

The data of electricity consumptions have been correlated to the price of electric energy. 
In Italy the price of electric energy for large users is based on rates that are fixed by the Electric Energy and Gas Authority (AEGG 181/06). The price varies according to time of day/night and on the cost for use of transmission grid, which depends on the monthly maximum power taken from the net and by amount of electric energy purchased at different fares.

Fig.2-3 and Table I show electric energy consumption during the PEAK period (F1 bracket) and the OFF PEAK period (F2-F3 bracket)

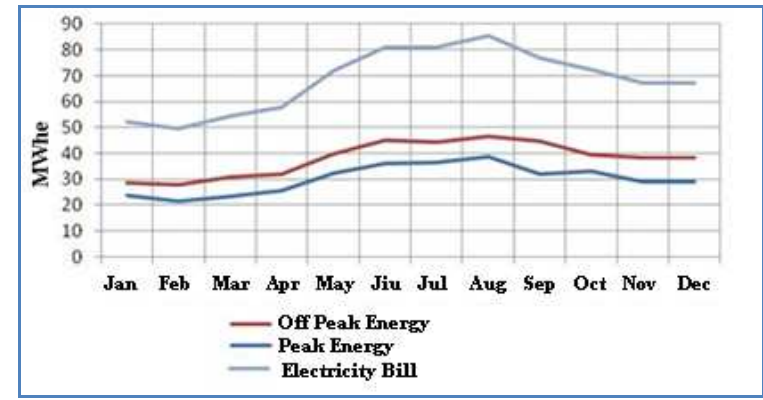

Fig. 2:Energy demand during the year 2007

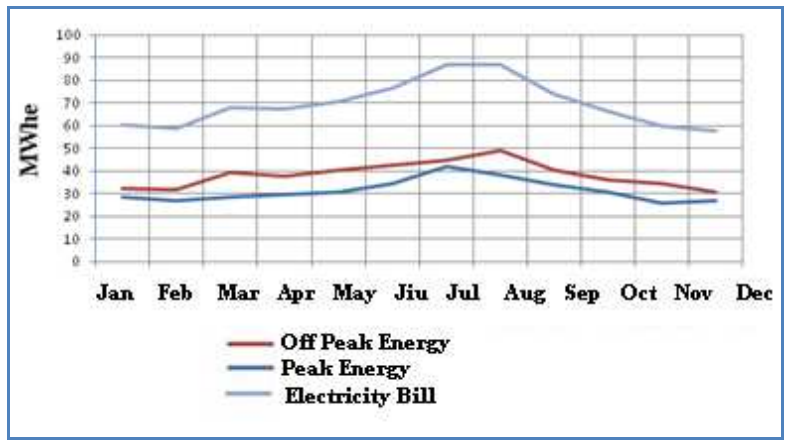

Fig.3: Energy demand during the year 2008

Analyzing the electricity consumption for Years 2007 $2008-2009$, the Authors have found out that the farm electricity demand was about 824.5 MWh/a.

Furthermore, the analysis of data have suggested that: - the power consumptions were higher in Summer Period and it was due to the increase of the demand for cooling energy produced by $\mathrm{n} .4$ vapor-compression refrigeration systems with maximum power of $\mathrm{kW} 92,4$.

- the power factor has assumed values between 0.7 and 0.9 and consequently the Farm have had pay a penalty for the reactive energy consumed, although the Farm had a power factor correction system.

The Authors have monitored the electric consumption for a period of two weeks in the following main department:

1) slaughterhouse and salami

2) mill

3) organic fertilizer production plant

4) others facility (outdoor lightening, offices, etc)

Table I. - Active and reactive energy consumption (MWh)

\begin{tabular}{|l|l|l|l|l|l|l|l|}
\hline \multicolumn{4}{|c|}{ Year 2007 } & \multicolumn{4}{c|}{ Year 2008} \\
\hline M. & $\begin{array}{l}\text { E.A } \\
\text { MWhe }\end{array}$ & $\begin{array}{l}\text { E.R } \\
\text { MWhe }\end{array}$ & $\cos \boldsymbol{\varphi}$ & M. & $\begin{array}{l}\text { E.A } \\
\text { MWhe }\end{array}$ & $\begin{array}{l}\text { E.R } \\
\text { MWhe }\end{array}$ & $\cos \boldsymbol{\varphi}$ \\
\hline Gen. & 52,29 & 55,18 & $\mathbf{0 , 6 9}$ & Gen. & 60,53 & 41,61 & $\mathbf{0 , 8 2}$ \\
\hline
\end{tabular}

\begin{tabular}{|c|c|c|c|c|c|c|c|}
\hline $\mathrm{Feb}$ & 49,44 & 38,51 & 0,79 & Feb & 58,63 & 37,08 & $\mathbf{0 , 8 5}$ \\
\hline Mar & 54,31 & 41,21 & 0,8 & Mar & 67,77 & 48,06 & $\mathbf{0 , 8 2}$ \\
\hline Apr & 57,86 & 46,54 & $\mathbf{0 , 7 8}$ & Apr & 67,17 & 49,69 & 0,8 \\
\hline Mag & 72,16 & 60,02 & 0,77 & Mag & 70,65 & 52,93 & 0,8 \\
\hline Giu & 81,16 & 68,19 & 0,77 & Giu & 76,46 & 60,79 & 0,78 \\
\hline Lug & 80,85 & 74,94 & $\mathbf{0 , 7 3}$ & Lug & 86,64 & 68,95 & 0,78 \\
\hline Ago & 85,51 & 72,44 & 0,76 & Ago & 86,95 & 70,11 & 0,78 \\
\hline Set & 76,71 & 65,56 & 0,76 & Set & 73,69 & 60,15 & 0,77 \\
\hline $\mathrm{Ott}$ & 72,52 & 54,8 & $\mathbf{0 , 8}$ & $\mathrm{Ott}$ & 66,42 & 54,01 & 0,78 \\
\hline Nov & 67,21 & 40,77 & 0,86 & Nov & 59,76 & 48,23 & 0,78 \\
\hline Dic & 67,01 & 39,5 & 0,86 & Dic & 57,36 & 37,08 & 0,84 \\
\hline \multicolumn{4}{|c|}{$\operatorname{Cos} \varphi$ mean monthly 0,78} & \multicolumn{4}{|c|}{$\operatorname{Cos} \varphi$ mean monthly0,8 } \\
\hline
\end{tabular}

During the year 2009 have been monitored the electric consumption during two week as shown in table II.

Table II. - Energy consumption during monitored weeks

\begin{tabular}{|l|l|l|}
\hline Sector & $\begin{array}{l}\text { Week } \\
\text { from 20/03/2009 to } \\
\mathbf{7 / 0 3 / 2 0 0 9}\end{array}$ & $\begin{array}{l}\text { Week } \\
\text { From 17/04/2009 } \\
\mathbf{4 / 0 4 / 2 0 0 9}\end{array}$ \\
\hline $\begin{array}{l}\text { slaughterhouse } \\
\text { and salami }\end{array}$ & $808 \mathrm{kWh}$ & $772 \mathrm{kWh}$ \\
\hline others facility & $733 \mathrm{kWh}$ & $595 \mathrm{kWh}$ \\
\hline purification plant & $496 \mathrm{kWh}$ & $484 \mathrm{kWh}$ \\
\hline mill & $115 \mathrm{kWh}$ & $124 \mathrm{kWh}$ \\
\hline
\end{tabular}

The higher consumption has been monitored for the slaughterhouse and the "others facility".

Analyzing the daily electric consumption recorded during the two weeks it has been possible observe an increasing demand of energy on Monday and Tuesday because of the pigs were slaughtered in those days.

Fig. 4 shows the comparison of the electric consumption monitored during the two weeks

The average daily consumption during the period monitored was $2063 \mathrm{kWh}$ and it was comparable with the daily consumption reported on the bills for the years 2007 and 2008 that was $2259 \mathrm{kWh}$.

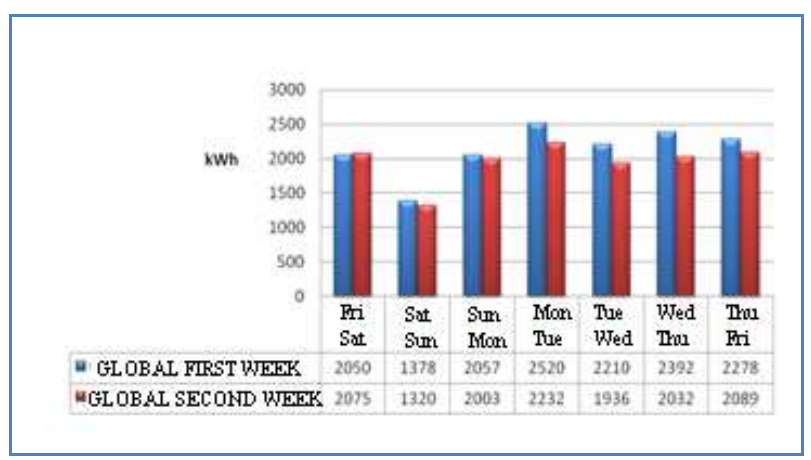

Fig. 4: daily electric demand

This result has showed, therefore, a substantial uniformity of power consumption during the year.

The proposed intervention to improve the energy efficiency of the farm are the following: 
- increase the efficiency of the power factor in order to reduce the reactive power consumed

- concentrate at least $67 \%$ of electricity consumption during the night or in the weekends period of time slot off peak (F2, F3)

\subsection{Thermal Demand}

The thermal energy needed for the various plants are due for the following utilities:

- $\quad$ heating of the birthing area and weaning shed

- air conditioning of sausage department

- heating of the water $\left(63^{\circ} \mathrm{C}\right)$. for the slaughter process

Thermal energy is produced by $\mathrm{n} 3$ boilers with a maximum power of $100 \mathrm{kWt}$

Fig. 5 shows the monthly average demand of thermal energy calculated in function of monthly consumption of LPG.

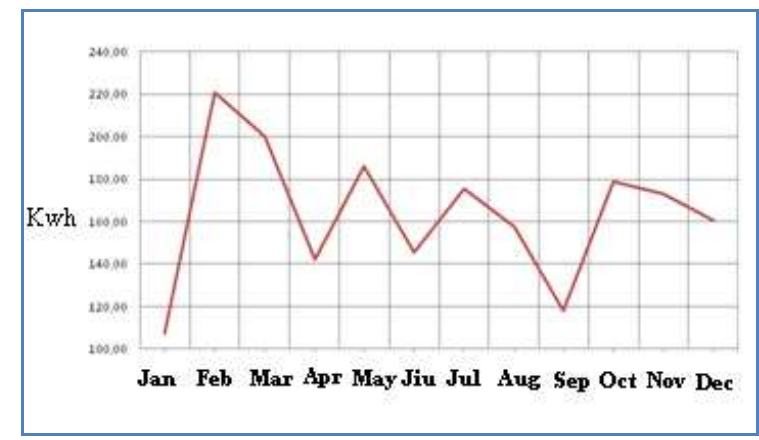

Fig. 5: Monthly demand of thermal energy (2008)

\subsection{Biogas production}

The production of biogas can be obtained by anaerobic digestion of the pig manure which provides a prime opportunity for combined heat and power (CHP) generation to satisfy onsite energy demands and/or energy exports.

The major differences between the technologies for converting organic wastes into biogas are construction effort and cost, land (space) demand and the ability to handle feed stocks with different dry matter concentrations.

Biogas derived from animal manures typically consists of [6]

- 55-65\% methane $\left(\mathrm{CH}_{4}\right)$,

- $\quad 35-45 \%$ carbon dioxide $\left(\mathrm{CO}_{2}\right)$,

- $\quad<3 \%$ nitrogen (N2) and other inert gases,

- $\quad 50$ - 200 ppm ammonia gas (NH3)

- $\quad 100-800$ ppm hydrogen sulphide (H2S).

The collected manure is conveyed to a pretreatment tank and then transferred by a pumping station to a treatment plant.

The solid fraction separated upstream of the digester can be composted or stored and carried as fertilizer on agricultural land, while the liquid fraction, rich in organic matter, is pumped in the digester.
Biogas formed in the anaerobic digester bubbles to the surface and may accumulate beneath a fixed rigid top, a flexible inflatable top, or a floating cover, depending on the type of digester. Then biogas is sent by a blower to the storage tank and pumped to the operating pressure required by CHP System. Prior to this, biogas may be processed to remove moisture, $\mathrm{H}_{2} \mathrm{~S}$, and $\mathrm{CO}_{2}$. Research on anaerobic pond performance indicates that under temperate climate conditions covered anaerobic ponds achieve annual average solids to methane conversion rates similar to more sophisticated heated and mixed digesters [7]

The slurry leaving the digester, will be deodorized, stabilized and accumulated in one or more storage basins and then utilized on agricultural land.

The hot exhaust gases from the gas turbine power generator will be directly piped to the existing steam boiler. The heat produced by CHP system is partially used to maintain the digester at $37^{\circ} \mathrm{C}$ in order to optimize the production of biogas

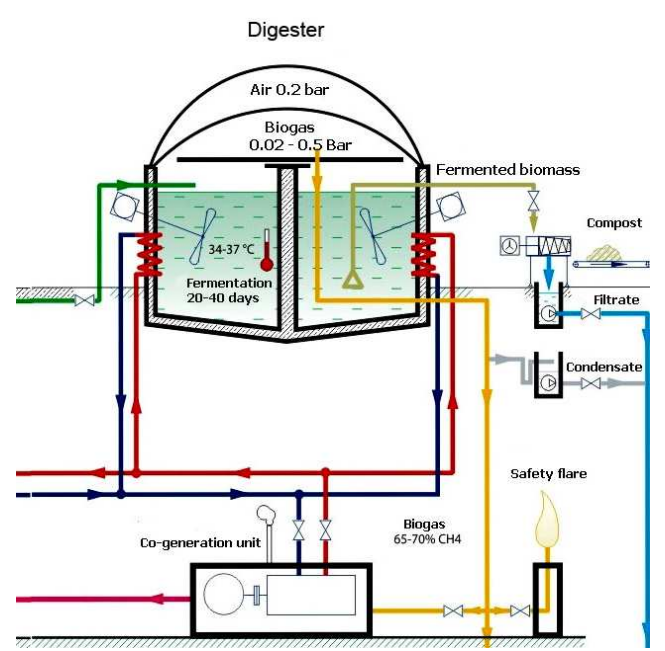

Fig. 6 - Biogas Layout

The environmental advantages of using anaerobic digestion for pig farm wastes include the reduction of odors, flies, and pathogens as well as decreasing greenhouse gas (GHG) and other undesirable air emissions [8]

Considering that 1 ton pig manure gives $25 \mathrm{~m}^{3}$ of biogas the farm have a potential production of about $590,000 \mathrm{~m}^{3}$ per year of biogas.

\subsection{CHP plant technology}

The CHP plant is the centre piece of the envisaged waste to energy scheme. For the scheme to work successfully a suitable CHP plant must fulfill a range of requirements, in particular:

- require little maintenance

- consistently operate efficiently

- high operational availability

- easily integrated with the existing heat and power infrastructure

- remote control capability

A condition of the study ahs been that the biogas fuelled CHP plant had to be integrated with the existing pig farming operation with minimal disruption. 
Micro gas turbine power generators has been identified as potential alternative energy conversion technology for the study.

Micro gas turbine power generators are compact SCADA packaged units which provide for remote control of all operations including independent or grid

synchronized electricity generation

The choice of potentiality and the typology of the cogeneration plant has required the analysis of energy needs, investment costs and economic benefits.

This analysis was performed using a specific computer codes [9].

Analyzing the electrical and thermal loads, the size of turbine available on the market has been selected a gas turbine with electrical power of $150 \mathrm{kWe}$.

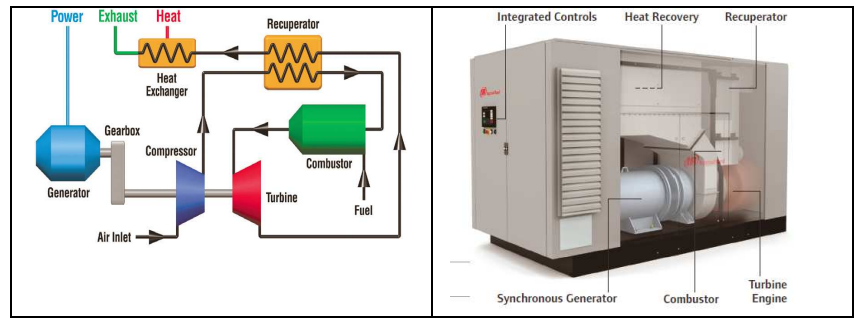

Fig. 7: layout of the Cogeneration Plant

The Fig. 8 shows electric and thermal power demands during the year.

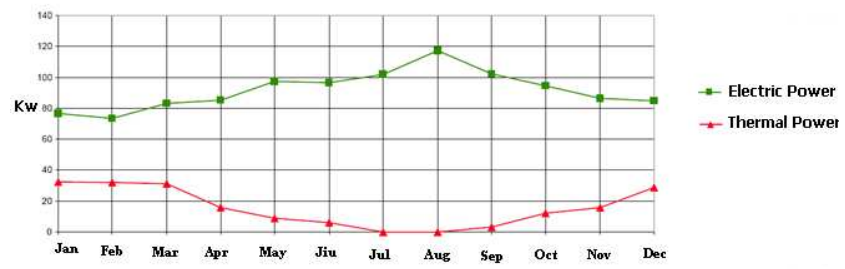

Fig. 8: Electric and thermal demands.

The Authors have chosen a scenario for the CHP plant that produces always maximum electric power.

Table 4 shows the main characteristic of the analyzed scenario.

Table III. - Characteristic of the proposed scenario

\begin{tabular}{|l|c|c|c|c|}
\hline $\begin{array}{c}\text { Proposed } \\
\text { System }\end{array}$ & $\begin{array}{c}\text { Type of } \\
\text { Fuel }\end{array}$ & $\begin{array}{c}\text { Fuel } \\
\text { Consump }\end{array}$ & $\begin{array}{c}\text { Power } \\
\text { (kW) }\end{array}$ & $\begin{array}{c}\text { Supply } \\
\text { energy } \\
\text { (MWh) }\end{array}$ \\
\hline $\begin{array}{l}\text { Electric } \\
\text { Power }\end{array}$ & & & & \\
\hline $\begin{array}{l}\text { Base } \\
\text { Load }\end{array}$ & Biogas & $\begin{array}{c}591.300 \\
\mathrm{~m}^{3}\end{array}$ & 150 & 609,0 \\
\hline $\begin{array}{l}\text { Peak } \\
\text { Load }\end{array}$ & $\begin{array}{c}\text { Electric } \\
\text { Power }\end{array}$ & $216 \mathrm{MWh}$ & 174 & 216,0 \\
\hline $\begin{array}{l}\text { To } \\
\text { Electric } \\
\text { network }\end{array}$ & & & & 376,0 \\
\hline & & Total & $\mathbf{3 2 4}$ & $\mathbf{1 ' 1 9 2}$ \\
\hline $\begin{array}{l}\text { Thermal } \\
\text { Power }\end{array}$ & & & & \\
\hline Base & Heat & & 210 & 104 \\
\hline
\end{tabular}

\begin{tabular}{|l|c|c|c|c|}
\hline Load & Recovered & & & \\
\hline $\begin{array}{l}\text { Peak } \\
\text { Load }\end{array}$ & $\begin{array}{c}\text { Natural } \\
\text { Gas }\end{array}$ & $4.310 \mathrm{~m}^{3}$ & 35 & 35 \\
\hline & & Total & $\mathbf{2 4 5}$ & $\mathbf{1 3 9}$ \\
\hline
\end{tabular}

This scenario generates $985,000 \mathrm{kWh}$ of electricity per annum from renewable biogas only.

With reference to the total demand of electricity energy, that was $824 \mathrm{MWh}$, it has been possible notice that:

- $\quad$ 609.0 MWh are furnished by the gas turbine

- $216 \mathrm{MWh}$ are furnished by the electrical grid

The generator achieves a load factor of $75 \%$. A split of $74 \%$ on-farm use of electricity and $26 \%$ electricity export was calculated.

The excess of energy production, that is 376,0 MWh could be sell to the national electric grid [10]

With reference to the total demand of thermal energy, that is $139 \mathrm{MWh}$, it has been possible notice that:

- $\quad 104.0$ MWh are furnished by the hot exhaust gases from the gas turbine

- 35 MWh are furnished by fossil fuel (methane)

\subsection{Economic feasibility}

The factors evaluated have been: total cost of equipment, cost of installation \& commissioning, economic life, exchange rate, interest rate, cost of operation and maintenance

The Table IV shows the parameters that characterize the economic feasibility of the scenario proposed

The return for the additional electricity exported into the network was assumed to be at a current market rate $(0.09$ $€ / \mathrm{kWh}$ ). The interest rate is $5 \%$.

The incentives have been calculated taking in account an all-inclusive price of $0.30 € / \mathrm{kWh}$ applicable in case of power plants less than $1 \mathrm{MW}$ [10]

Table IV. - Economic feasibility

\begin{tabular}{|c|c|c|}
\hline Cost of Intervention & $€$ & 760.000 \\
\hline Income from production & $€$ & 295.650 \\
\hline Annual Income & $€ /$ year & 390.514 \\
\hline TIR & $\%$ & $21,1 \%$ \\
\hline Payback & years & 2,5 \\
\hline VAN & $€$ & 964.032 \\
\hline
\end{tabular}

Income are due to a combination of cash flows from both the incentives for the production of electricity from renewable sources ( $€ 295,650$ / year) and from savings on energy supplies ( $€$ 94,864 / year).

The proposed CHP plant, in addition to energy and economic benefits illustrated also permit to obtain environmental benefits: there is a significant reduction of annual emissions $\mathrm{CO}_{2}$ equal to 1746 tons. The typology of CHP chosen implies a clear imbalance in the production of thermal energy that would be far superior to the needs of the farm so further developments of the study will provide to use the surplus heat to produce cooling energy [11],[12] 
A further improvement of efficiency of the plant could be obtained with a new configuration of the architectural system with the replacement of existing vaporcompression chillers with absorption chillers powered by waste heat of the CHP.

\section{Conclusions}

The analysis of the farm energy consumption and electrical and thermal demands has identified the following possible interventions:

- avoid the overlapping of the operation of the machines with higher power consumption in order to eliminate the overlap of peak power demand that required the signing of electric contracts more burdensome

- improve the power factor correction system, in order to avoid the payment of penalties due to the consumption of reactive energy

-adoption of a CHP system that use a gas turbine, fueled by biogas from pig manure with power of $150 \mathrm{~kW}$.

Biogas electricity generation schemes realize a number of benefits:

- almost total self-sufficiency needs of both thermal and electric energy;

- achieves a payback period of 2.4 years and yields an annual profit of $€ 390,500$.

Apart from the pig farms' internal financial benefits of combined heat and power generation such schemes have secondary environmental and social benefits. Recovering biogas methane from waste treatment systems can greatly reduce fugitive methanogenic

GHG emissions. It is estimated that the scheme under investigation can avoid more than $1800 \mathrm{tCO}_{2}$ equi $\mathrm{GHG}$ emissions per annum. A further environmental and social benefit of the model is the avoidance of odors typically emitted by uncontained alternative treatment systems.

The study carried out has shown that under given circumstances a biogas fuelled CHP plant makes both economic and environmental sense.

\section{References}

[1] Electricity generation from pig farm biogas EECA Reference Number: 1.490

[2] Sergio Piccinini State Of The Art Of Biogas In Italy Workshop :Biogas - a promising renewable energy source for Europe December 11, 2008 - European Parliament, Brussels, Belgium

[3] http://www.eurobserv-er.org

[4] www.iea-biogas.net - Bioenergy task 37

[5] Technology Characterization:Steam Turbines Energy Nexus Group - Environmental Protection Agency Climate Protection Partnership Division

Washington, DC

[6] Craggs, R.; Park, J.; Heubeck, S. (2008). "Methane emissions from anaerobic ponds on a piggery and a dairy farm in New Zealand". Australian Journal of Experimental Agriculture, 48: 142-146 ]

[7] Kurt Roos, An evaluation of a covered anaerobic lagoon for flushed dairy cattle manure stabilization and biogas production - US. EPA

[8] Burke, Dennis A. June 2001. Dairy waste anaerobic digestion handbook: options for recovering beneficial products from dairy manure. Environmental Energy Company, Olympia, WA.

[9]CHP-Natural Resources Canada- www.retscreen.net [10] Www.autorità.energia.it - AEGG

[11] Patania F., Gagliano A, Nocera F (2007). Innovative technology, energy saving and respect for environmental in hospital HVAC systems: the real case of "S. Marco Hospital" in typical Mediterranean city (part one) CLIMAMED 2007. p. 1079-1088, Aicarr, ISBN/ISSN: 9788895620022

[12] Patania F., C. Manzo, A. Gagliano, F. Nocera (2004). How to get energy economics and environmental benefits: an applied research for real case. In: III Conference Economics and Management of Energy in Industry. Lisbon, Portugal, April 2004, p. 1-10 